\title{
Pengaruh Penambahan Dosis Pupuk Fosfat terhadap Pertumbuhan dan Hasil Tanaman Jagung (Zea Mays, L) pada Inceptisol asal Jatinangor
}

\section{Eso Solihin, Rija Sudirja, Apong Sandrawati, Maya Damayani, dan Nadia N. Kamaluddin}

Departemen Ilmu Tanah dan Sumberdaya Lahan, Fakultas Pertanian Universitas Padjadjaran

Jl. Raya Bandung Sumedang Km 21 Jatinangor

Korespondensi: eso.soilhin@unpad.ac.id

\begin{abstract}
Corn is one of the important commodities in Indonesia that is not only used as food but also as livestock feed and industry, as well as alternative fuels (biofuels). Degradation of soil fertility became one of the factors limiting the production of this commodity. The purpose of this study was to determine the effect of innovative phosphate fertilizer on the growth and yield of sweet corn on Inceptisols with low fertility. The research was conducted from September 2018 to January 2019. Randomized Block Design (RBD) was used with treatment arrangements as follows: $A=$ Control (without P), B = Recommended NPK dosage ( $300 \mathrm{~kg} / \mathrm{ha}$ urea $+150 \mathrm{~kg} / \mathrm{ha} \mathrm{SP}-36+50 \mathrm{~kg} / \mathrm{ha} \mathrm{K}), C$ $=1 / 4 P(300 \mathrm{~kg} / \mathrm{ha} \mathrm{N}+25 \mathrm{~kg} / \mathrm{haSP}-36 \mathrm{Inv}+50 \mathrm{~kg} / \mathrm{ha} \mathrm{K}), D=1 / 2 \mathrm{P}(300 \mathrm{~kg} / \mathrm{ha} \mathrm{N}+50 \mathrm{~kg} / \mathrm{ha} \mathrm{SP}-$ $36 \mathrm{Inv}+50 \mathrm{~kg} / \mathrm{ha} \mathrm{K}), E=3 / 4 P(300 \mathrm{~kg} / \mathrm{ha} \mathrm{N}+75 \mathrm{~kg} / \mathrm{ha} S P-36 \mathrm{Inv}+50 \mathrm{~kg} / \mathrm{ha} \mathrm{K}), F=1 P(300 \mathrm{~kg}$ / ha N + $100 \mathrm{~kg} / \mathrm{haSP}-36 \mathrm{Inv}+50 \mathrm{~kg} / \mathrm{ha} \mathrm{K}), G=11 / 4 P(300 \mathrm{~kg} / \mathrm{ha} \mathrm{N}+125 \mathrm{~kg} / \mathrm{ha} \mathrm{SP}-36 \mathrm{Inv}+50$ $\mathrm{kg} / \mathrm{ha} \mathrm{K}), H=1 \frac{1}{2} P(300 \mathrm{~kg} / \mathrm{ha} \mathrm{N}+50 \mathrm{~kg} / \mathrm{ha} \mathrm{SP}-36 \mathrm{Inv}+150 \mathrm{~kg} / \mathrm{ha} \mathrm{K}), I=13 / 4 \mathrm{P}(300 \mathrm{~kg} / \mathrm{ha} \mathrm{N}$ $+175 \mathrm{~kg} / \mathrm{ha} \mathrm{SP-36} \mathrm{Inv}+50 \mathrm{~kg} / \mathrm{ha} \mathrm{K}$ ), $J=0$ (Without NPK). The results showed that the SP-36 innovative inorganic fertilizer that was given together with urea and KCl increased the yield of sweet corn equivalent to the standard yield of corn in NPK fertilizer. The treatment with the highest results is 11/2 P doses of SP-36 innovation results and P from standard NPK both of which are equivalent to $150 \mathrm{~kg} / \mathrm{ha} P$. The yield of sweet corn yields ranges from 21.16 - 21.56 tons per hectare.
\end{abstract}

Keywords: fertilizer innovation, sweet corn, soil fertility

\section{PENDAHULUAN}

Jagung merupakan salah satu komoditas penting di Indonesia. Komoditas ini termasuk salah satu komoditas pangan nasional yang menjadi makanan pokok utama setelah beras, sehingga menjadi penyangga ketahanan pangan nasional. Pemanfaatan jagung di Indonesia juga tidak hanya sebagai bahan pangan (food) tetapi juga digunakan sebagai bahan pakan (feed) dan industri, bahkan sudah mulai digunakan sebagai bahan bakar alternatif (biofuel). Hingga saat ini pengembang komoditas jagung masih diprioritaskan. Hal ini karena Indonesia masih terus mengandalkan impor untuk memenuhi kekurangan produksi jagung dalam negeri. Menurut Badan Pusat Statistik (2018), impor jagung Indonesia mencapai 737.228 ton dengan tiga negara asal impor terbesar berasal dari Argentina sebanyak 326.580 ton, Brasil sebesar 222.578 ton, dan Amerika Serikat (AS) sejumlah 186.142 ton. Hal ini menandakan bahwa produksi jagung
Indonesia masih dihadapkan pada berbagai kendala.

Kendala produksi pertanian dalam hal ini untuk komoditas jagung, salah satunya adalah degradasi kesuburan tanah yang menjadi media tumbuh tanaman. Penurunan kualitas tanah ini dapat berupa kehilangan bahan organik dan unsur hara akibat pencucian oleh curah hujan yang tinggi, rusaknya struktur tanah akibat pengolahan terus menerus dan input pupuk anorganik yang berlebihan (Olowoake, 2018). Oleh karena itu untuk mempertahankan angka produksi jagung nasional, diperlukan upaya yang mendukung optimalisasi lahan pertanian, salah satunya dengan pemanfaat tanah-tanah yang kurang subur dengan pengelolaan yang tepat.

Inceptisol merupakan salah satu jenis tanah dengan sebaran yang cukup luas di Kecamatan Jatinangor, khususnya di area kebun percobaan Fakultas Pertanian Universitas Padjadjaran. Inceptisol pada 
umumnya memiliki tingkat kesuburan yang rendah diantaranya karena ketersediaan $\mathrm{P}$ yang rendah. Hasil analisis tanah Inceptisol Jatinangor adalah sebagai berikut; kandungan C-organik rendah $(1,97 \%)$, N-total rendah $(0,20 \%), \mathrm{P}_{2} \mathrm{O}_{5}$ total rendah $(21,22 \mathrm{mg} / 100 \mathrm{~g})$, $\mathrm{K}_{2} \mathrm{O}$ total rendah $(13,88 \mathrm{mg} / 100 \mathrm{~g})$, Kejenuhan basa sedang $(50,16 \%)$, KTK sedang $(19,26 \mathrm{cmol} / \mathrm{kg})$ dan $\mathrm{pH}$ agak masam $(5,67)$. Pemanfaatan tanah untuk budidaya tanaman lebih lanjut dengan tingkat kesuburan rendah ini memerlukan input pupuk khususnya pupuk $\mathrm{P}$ karena unsur ini sangat dipengaruhi oleh kondisi $\mathrm{pH}$ pada tanah dengan kriteria agak masam.

Masalah lain yang ditimbulkan oleh penggunaan pupuk fosfor ialah efisiensinya yang rendah karena fiksasi fosfor yang cukup tinggi di dalam tanah masam. Pemberian pupuk fosfat dalam jumlah besar oleh pengaruh waktu dapat berubah menjadi fraksi yang sukar larut. Fosfor dalam tanah sukar larut, sehingga sebagian besar tidak tersedia bagi tanaman (Leiwakabessy dan Sutandi, 2004). Aplikasi P tersedia dari SP-36 hasil inovasi dengan dosis yang tepat dalam penelitian ini diharapkan menjadi alternatif pupuk yang dapat dimanfaatkan untuk menunjang peningkatan produksi jagung manis melalui fase pertumbuhan dan perkembangan yang baik serta komponen hasil tanaman yang optimal.

\section{METODOLOGI}

Percobaan ini dilaksanakan di Kebun Percobaan Fakultas Pertanian Unpad, Kampus Jatinangor, Kabupaten Sumedang Jawa Barat. Ketinggian tempat sekitar \pm 750 meter di atas permukaan laut. Analisis tanah dilakukan di Laboratorium Kimia Tanah dan Nutrisi Tanaman, Fakultas Pertanian Universitas Padjadjaran. Percobaan berlangsung mulai bulan September 2018 sampai dengan Januari 2019.

Bahan yang digunakan terdiri atas benih jagung manis varietas "Talenta" yang telah memenuhi kriteria uji daya kecambah pada tahap penelitian pendahuluan, pupuk anorganik SP-36 hasil inovasi yang telah memenuhi standar baku pupuk anorganik, dan tanah inceptisol jatinangor dengan kandungan $\mathrm{P}$ yang rendah. Alat yang digunakan dalam percobaan terdiri dari peralatan lapangan, peralatan laboratorium dan perangkat untuk analisis data. Percobaan menggunakan rancangan acak kelompok (RAK), sepuluh perlakuan dan tiga ulangan sehingga jumlah petak percobaan berjumlah 30 petak. Petak percobaan yang digunakan berukuran $4 \mathrm{~m}$ x $5 \mathrm{~m}$. Susunan perlakuan secara lengkap dapat dilihat pada Tabel 1.

Tabel 1 Susunan perlakuan dosis pupuk SP36 hasil inovasi dengan urea dan $\mathrm{KCl}$ untuk tanaman jagung

\begin{tabular}{|c|c|c|c|c|}
\hline \multirow{2}{*}{ Perlakuan } & \multirow{2}{*}{$\begin{array}{c}\text { Pupuk P } \\
\text { hasil inovasi } \\
\text { SP-36 }\end{array}$} & \multicolumn{3}{|c|}{ Pupuk NPK } \\
\hline & & Urea & SP-36 & $\mathrm{KCl}$ \\
\hline & 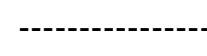 & $\mathrm{kg} \mathrm{ha}^{-1}$ & 1 ----- & -.-- \\
\hline A (Tanpa P) & 0 & 300 & 0 & 50 \\
\hline $\begin{array}{l}\mathrm{B}(\mathrm{N}, \mathrm{P}, \mathrm{K} \\
\text { Tunggal) }\end{array}$ & 0 & 300 & 150 & 50 \\
\hline $\mathrm{C}(1 / 4 \mathrm{P})$ & 25 & 300 & 0 & 50 \\
\hline $\mathrm{D}(1 / 2 \mathrm{P})$ & 50 & 300 & 0 & 50 \\
\hline $\mathrm{E}(3 / 4 \mathrm{P})$ & 75 & 300 & 0 & 50 \\
\hline$F(1 P)$ & 100 & 300 & 0 & 50 \\
\hline $\mathrm{G}(11 / 4 \mathrm{P})$ & 125 & 300 & 0 & 50 \\
\hline $\mathrm{H}(1$ 1/2 P) & 150 & 300 & 0 & 50 \\
\hline $\mathrm{I}(13 / 4 \mathrm{P})$ & 175 & 300 & 0 & 50 \\
\hline $\begin{array}{l}\text { J (Tanpa } \\
\mathrm{N}, \mathrm{P}, \mathrm{K})\end{array}$ & 0 & 0 & 0 & 0 \\
\hline
\end{tabular}

Dosis perlakuan dasar dan perlakuan kontrol $\mathrm{N}, \mathrm{P}, \mathrm{K}$ disetarakan mendekati kandungan $\mathrm{N}$-Urea, $\mathrm{P}_{2} \mathrm{O}_{5}$, dan $\mathrm{K}_{2} \mathrm{O}$ yang lazim digunakan, sedangkan dosis pupuk SP-36 hasil inovasi menggunakan dosis sesuai ketentuan pengujian berdasarkan Peraturan Menteri Pertanian Nomor 36/PERMENTAN/SR/10/ 2017 Tahun 2017, tentang Pendaftaran Pupuk An-organik. Respons tanaman yang diamati terdiri atas pertumbuhan tanaman (tinggi dan jumlah daun,), mulai umur 14 hari setelah tanam (HST), 28, 42, hingga 56 HST (vegetatif 
maksimum), komponen Hasil (bobot tongkol berkelobot segar per tanaman, bobot tongkol kupasan segar per tanaman diameter tongkol per tanaman dan panjang tongkol per tanaman. Selain itu ditunjang dengan analisis tanah awal, analisis pupuk SP-36 hasil inovasi serta pengamatan gejala serangan hama dan penyakit tanaman. Pengujian signifikansi untuk mengetahui pengaruh perlakuan digunakan uji Fisher pada taraf nyata 5\%. Apabila terdapat perbedaan yang nyata, pengujian dilanjutkan dengan uji jarak berganda Duncan pada taraf 5\%.

Pelaksanaan Percobaan dimulai dengan pembuatan petak pengujian. Satuan percobaan petak (bedengan) berukuran $4 \mathrm{~m} \mathrm{x}$ $5 \mathrm{~m}$. Jarak antar petak $50 \mathrm{~cm}$ dan jarak antar ulangan (kelompok) $75 \mathrm{~cm}$. Jarak antar baris tanaman $75 \mathrm{~cm}$, dan jarak antar tanaman dalam baris $40 \mathrm{~cm}$. Setiap petak dibuat 66 lubang tanam yang diisi dua buah benih jagung per lubang tanam (Syukur dan Rifianto, 2013). Satuan percobaan diletakkan secara acak dalam satu ulangan (kelompok). Ulangan ditentukan berdasarkan gradient kesuburan tanah. Pemupukan Urea, SP-36 dan KCl dilakukan dengan cara dibenamkan $5 \mathrm{~cm}$ disamping tanaman. Jarak lubang pupuk dengan tanaman sekitar $5 \mathrm{~cm}$. Pupuk urea dibagi menjadi 3 kali pemberian yaitu pada umur 7 HST, 21 HST dan 42 HST, sedangkan untuk pupuk SP-36 dan $\mathrm{KCl}$ diberikan pada saat awal tanam. Pemberian Pupuk anorganik Pupuk SP-36 sebagai pupuk yang diuji, diaplikasikan pada awal tanam sesuai dengan rekomendasi aplikasi dan dosis diberikan sesuai masing-masing perlakuan.

Pemeliharaan yang dilakukan pada pengujian ini mengacu pada budidaya standar yang dilaksanakan untuk tanaman jagung yang meliputi: Penyiraman setiap hari namun jika ada hujan penyiraman tidak dilakukan. Penyiraman dilakukan mulai dari awal tanam sampai panen, penyiangan dan pengendalian gulma, serta pengendalian hama dan penyakit termasuk cara preventif.

Pemanenan hasil jagung dilakukan setelah berumur 88 hari setelah tanam. Kemudian ditimbang sehingga diperoleh nilai rata-rata per tanaman. Selanjutnya bobot hasil yang sudah ditimbang dan dikonversikan ke dalam hasil per hektar dengan faktor koreksi $20 \%$.

\section{HASIL DAN PEMBAHASAN}

\subsection{Tinggi Tanaman}

Tinggi tanaman jagung merupakan salah satu parameter yang penting karena merupakan ciri pertumbuhan tanaman yang berkaitan dengan faktor dan komponen tumbuh lainnya, seperti lingkungan yang menekan atau mendorong pertumbuhan, jumlah daun, luas daun, serta perakaran yang akan berkembang. Tinggi tanaman merupakan parameter yang langsung dipengaruhi oleh ketersediaan unsur hara dan serapan hara oleh akar tanaman (Roosmarkam dan Yuwono, 2002).

Pertumbuhan tinggi tanaman berdasarkan data pengamatan dapat dilihat pada dilihat pada Tabel 2. Hasil analisis dari berbagai perlakuan pupuk menunjukkan pengaruh berbeda nyata terhadap tinggi tanaman pada semua fase pertumbuhan yaitu pada 14 sampai 56 HST.

Tinggi tanaman pada pengamatan 14 HST mulai menunjukkan perbedaan pengaruh yang signifikan dari perlakuan pupuk $\mathrm{P}$ yang diberikan. Sebagian besar perlakuan dengan penambahan SP-36 hasil inovasi ini memperlihatkan pertumbuhan tinggi tanaman yang lebih baik seperti halnya perlakuan NPK standar. Pada fase selanjutnya yaitu 28 HST hingga akhir vegetatif menunjukkan bahwa perlakuan pupuk $\mathrm{P}$ terhadap pertumbuhan tinggi tanaman jagung mulai menunjukkan pengaruh yang tetap. Perlakuan dosis $\mathrm{P}$ mulai dari 1 dosis hingga $13 / 4$ dosis $\mathrm{P}$ menunjukkan pertumbuhan tinggi yang lebih baik dari perlakuan lainnya.

Pada fase vegetatif akhir (56 HST) perlakuan G dan H (Pupuk SP-36 hasil inovasi, dengan dosis 125 dan $150 \mathrm{~kg} / \mathrm{ha}$ ) menunjukan nilai yang paling tinggi. Hal ini menunjukkan bahwa Dosis $150 \mathrm{Kg} / \mathrm{Ha} \mathrm{Sp36}$ adalah dosis optimum untuk mencapai pertumbuhan 
optimal tanaman jagung, penambahan dosis tidak akan berpengaruh pada peningkatan tinggi tanaman. Ketersediaan fosfor dalam tanah akan memperbaiki pertumbuhan akar yang akan berpengaruh kepada seluruh performa pertumbuhan tanaman, termasuk tinggi tanaman. Peningkatan dosis pupuk $\mathrm{N}$ dan $\mathrm{P}$ akan mempengaruhi serapan unsur hara tanaman, hal ini akan berpengaruh terhadap tinggi tanaman (Arain et. al., 1989 dalam Masood et. al., 2011; Ayub et. al., 2002). Hal ini bertentangan dengan Pupitasari dkk. (2018) yang menyatakan bahwa penambahan dosis pupuk $\mathrm{P}$ tidak berpengaruh nyata terhadap tinggi tanaman. Dalam hal ini, faktor jenis tanah harus dipertimbangkan.

Tabel 2 Data hasil analisis tinggi tanaman jagung pada fase vegetatif

\begin{tabular}{|c|c|c|c|c|}
\hline \multirow{2}{*}{ Perlakuan } & $14 \mathrm{HST}$ & $28 \mathrm{HST}$ & 42 HST & 56 HST \\
\hline & \multicolumn{4}{|c|}{ 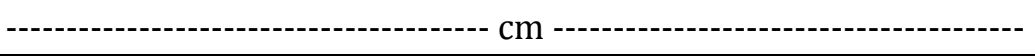 } \\
\hline$A=$ Tanpa $P$ & $13,54 c$ & $45,94 \mathrm{~cd}$ & $85,47 \quad b$ & $140,87 \mathrm{bc}$ \\
\hline $\mathrm{B}=\mathrm{N}, \mathrm{P}, \mathrm{K}$ (Tunggal) & $15,95 \mathrm{bc}$ & $49,40 \mathrm{~b}$ & $95,43 \mathrm{ab}$ & $150,13 \mathrm{ab}$ \\
\hline$C=1 / 4 \mathrm{P}$ & $16,41 \mathrm{~b}$ & $46,53 \mathrm{c}$ & $91,30 \mathrm{ab}$ & $136,53 \mathrm{c}$ \\
\hline$D=1 / 2 P$ & $16,03 \mathrm{~b}$ & $49,56 \mathrm{~b}$ & $94,13 \mathrm{ab}$ & $137,93 \mathrm{c}$ \\
\hline$E=3 / 4 P$ & $13,67 \mathrm{c}$ & $48,71 \mathrm{bc}$ & $95,47 \mathrm{ab}$ & $143,73 \mathrm{bc}$ \\
\hline $\mathrm{F}=1 \mathrm{P}$ & $16,07 \mathrm{~b}$ & $51,43 \mathrm{ab}$ & $99,27 \mathrm{ab}$ & $145,93 \mathrm{~b}$ \\
\hline $\mathrm{G}=1 \frac{1}{4} \mathrm{P}$ & 19,29 a & 54,08 a & 109,73 a & $152,80 \mathrm{ab}$ \\
\hline$H=11 / 2 P$ & $16,31 \mathrm{~b}$ & 54,59 a & 109,00 a & 155,33 a \\
\hline $\mathrm{I}=13 / 4 \mathrm{P}$ & $14,47 \mathrm{bc}$ & $52,92 \mathrm{ab}$ & $101,29 a b$ & $146,93 \mathrm{~b}$ \\
\hline $\mathrm{J}=0$ (Tanpa N,P,K Tunggal) & $14,15 \mathrm{bc}$ & $42,99 \mathrm{~d}$ & $82,07 \quad b$ & $133,93 \mathrm{c}$ \\
\hline
\end{tabular}

Keterangan: Angka rerata yang diikuti huruf yang sama tidak memberikan perbedaan nyata berdasarkan Uji Jarak Berganda Duncan pada taraf $5 \%$.

\subsection{Jumlah Daun}

Hasil perhitungan jumlah daun tanaman jagung manis pada berbagai perlakuan pada pengamatan 14 sampai 56 HST dapat dilihat pada Tabel 3. Jumlah daun tanaman jagung dicatat untuk setiap perlakuan pada saat umur 14, 28, 42, 56 HST, diambil beberapa sampel kemudian dirata-ratakan.

Tabel 3 Hasil analisis jumlah daun tanaman jagung pada fase vegetatif

\begin{tabular}{|c|c|c|c|c|}
\hline Perlakuan & 14 HST & 28 HST & $42 \mathrm{HST}$ & 56 HST \\
\hline$A=$ Tanpa $P$ & $3,80 \mathrm{a}$ & $7,87 \mathrm{a}$ & $10,27 \mathrm{a}$ & $13,93 \mathrm{bc}$ \\
\hline $\mathrm{B}=\mathrm{N}, \mathrm{P}, \mathrm{K}$ (Tunggal) & $3,80 \mathrm{a}$ & $7,53 \mathrm{a}$ & 10,93 a & $14,60 \mathrm{ab}$ \\
\hline$C=1 / 4 P$ & $4,33 \mathrm{a}$ & $7,97 \mathrm{a}$ & 10,60 a & $14,33 \mathrm{ab}$ \\
\hline$D=1 / 2 P$ & $4,20 \mathrm{a}$ & $7,80 \mathrm{a}$ & 10,73 a & $14,60 \mathrm{ab}$ \\
\hline$E=3 / 4 P$ & $3,93 \mathrm{a}$ & $7,87 \mathrm{a}$ & 10,87 a & $14,60 \mathrm{ab}$ \\
\hline $\mathrm{F}=1 \mathrm{P}$ & $4,07 \mathrm{a}$ & $8,27 \mathrm{a}$ & $10,73 \mathrm{a}$ & $14,60 \mathrm{ab}$ \\
\hline$G=1 \frac{1}{4} P$ & $4,27 \mathrm{a}$ & $8,13 \mathrm{a}$ & 11,53 a & 15,40 a \\
\hline$H=11 / 2 P$ & $3,93 \mathrm{a}$ & $8,20 \mathrm{a}$ & $11,40 \mathrm{a}$ & 15,13 a \\
\hline $\mathrm{I}=13 / 4 \mathrm{P}$ & $3,80 \mathrm{a}$ & $7,47 \mathrm{a}$ & 10,47 a & $14,33 a b$ \\
\hline $\mathrm{J}=0$ (Tanpa N,P,K, Tunggal $)$ & $3,73 \mathrm{a}$ & $7,13 \mathrm{a}$ & 9,80 a & $12,93 \mathrm{c}$ \\
\hline
\end{tabular}

Keterangan: Angka rerata yang diikuti huruf yang sama tidak berbeda nyata berdasarkan Uji Jarak Berganda Duncan pada Taraf $5 \%$. 
Pada umur tanaman 56 HST rataan jumlah daun tertinggi terdapat pada perlakuan dosis pupuk P lebih dari 1 kali dosis (perlakuan G dan $\mathrm{H}$ ). Penambahan dosis diatas $150 \mathrm{Kg} / \mathrm{Ha}$ SP 36 tidak berbeda nyata dalam peningkatan jumlah daun. Jika dibandingkan dengan perlakuan control (tanpa pupuk) dan tanpa pupuk $\mathrm{P}$, maka penambahan dosis $\mathrm{P}$ berpengaruh nyata dalam meningkatkan jumlah daun. Hal ini sejalan dengan hasil penelitian Fadilah dan Akbar (2015) yang menyatakan bahwa perlakuan pupuk $P$ berpengaruh nyata terhadap jumlah daun pada umur 30 dan 45 HST (masa vegetatif).

Pada jaringan tanaman, $\mathrm{P}$ berperan dalam hampir semua proses reaksi biokimia. Peran $\mathrm{P}$ yang sangat penting sejak fase awal tanaman adalah dalam proses penangkapan energi cahaya matahari dan transformasi menjadi energi biokimia. Selain itu, P merupakan komponen penyusun membran sel tanaman, penyusun enzim-enzim, penyusun co-enzim, nukleotida (bahan penyusun asam nukleat), $\mathrm{P}$ juga ambil bagian dalam sintesis protein, terutama yang terdapat pada jaringan hijau, sintesis karbohidrat, pembentukan akar halus dan rambut akar, meningkatkan ketahanan tanaman agar tanaman tidak mudah rebah serta memperbaiki kualitas tanaman. Kecukupan P pada setiap fase pertumbuhan dan perkembangan tanaman jagung mendukung pertumbuhan tinggi dan jumlah daun yang optimal (Gul et all., 2015; Santner et al., 2014).

\subsection{Hasil Tanaman Jagung}

Komponen hasil jagung manis ditunjukkan oleh keragaan jagung secara kuantitatif terhadap komponen hasil yang terdiri atas panjang tongkol jagung manis, diameter tongkol jagung manis bobot jagung yang masih berkelobot dan bobot jagung tanpa kelobot (Tabel 4). Komponen utama dari hasil tanaman jagung adalah bobot jagung (dengan kelobot atau tanpa kelobot). Perlakuan dosis $\mathrm{P}$ berbeda nyata terhadap bobot jagung.

Tabel 4 Data hasil pengukuran komponen hasil tanaman jagung (ukuran dan berat jagung)

\begin{tabular}{|c|c|c|c|c|c|}
\hline \multirow[t]{2}{*}{ Perlakuan } & $\begin{array}{l}\text { Panjang } \\
\text { Tongkol }\end{array}$ & $\begin{array}{c}\text { Diameter } \\
\text { Tongkol }\end{array}$ & $\begin{array}{c}\text { Bobot } \\
\text { dengan } \\
\text { Kelobot }\end{array}$ & $\begin{array}{c}\text { Bobot } \\
\text { tanpa } \\
\text { Kelobot }\end{array}$ & \multirow{2}{*}{$\begin{array}{c}\text { Konversi } \\
\text { Hasil jagung } \\
\text { Kg/ha }\end{array}$} \\
\hline & \multicolumn{2}{|c|}{---------- cm --------- } & \multicolumn{2}{|c|}{--------------- gr ------------- } & \\
\hline$A=$ Kontrol & $18,29 \mathrm{a}$ & $4,37 \mathrm{a}$ & $309,57 \mathrm{~d}$ & $214,20 \quad c$ & $16.510,06$ \\
\hline $\mathrm{B}=\mathrm{N}, \mathrm{P}, \mathrm{K}$ (Tunggal) & $19,71 \mathrm{a}$ & $4,69 \mathrm{a}$ & $396,6 \mathrm{ab}$ & $289,60 \mathrm{ab}$ & $21.155,34$ \\
\hline$C=1 / 4 \mathrm{P}$ & $18,59 \mathrm{a}$ & $4,53 \mathrm{a}$ & $355,33 \mathrm{c}$ & $261,53 \quad b$ & $18.950,92$ \\
\hline$D=1 / 2 P$ & $19,10 \mathrm{a}$ & $4,55 \mathrm{a}$ & $360,27 \mathrm{c}$ & $262,80 \mathrm{~b}$ & $19.214,03$ \\
\hline$E=3 / 4 P$ & $19,47 \mathrm{a}$ & $4,23 \mathrm{a}$ & $365,33 \mathrm{bc}$ & $264,10 \quad b$ & $19.484,25$ \\
\hline $\mathrm{F}=1 \mathrm{P}$ & $19,66 \mathrm{a}$ & $4,48 \mathrm{a}$ & $378,09 \mathrm{abc}$ & $271,29 \quad b$ & $20.164,78$ \\
\hline$G=11 / 4 P$ & $20,43 \mathrm{a}$ & $4,49 \mathrm{a}$ & $384,77 \mathrm{abc}$ & $281,33 \mathrm{ab}$ & $20.520,68$ \\
\hline$H=11 / 2 P$ & $20,66 \mathrm{a}$ & $4,65 \mathrm{a}$ & $404,30 \mathrm{a}$ & 304,73 a & $21.562,45$ \\
\hline $\mathrm{I}=13 / 4 \mathrm{P}$ & 18,33 a & $4,55 \mathrm{a}$ & $390,27 \mathrm{abc}$ & $282,67 \mathrm{ab}$ & $20.814,01$ \\
\hline $\mathrm{J}=0$ (Tanpa N,P,K & $17,65 \mathrm{a}$ & $4,30 \mathrm{a}$ & $295,70 \mathrm{~d}$ & $202,83 \mathrm{c}$ & $15.770,51$ \\
\hline
\end{tabular}

Keterangan: Angka rerata yang diikuti huruf yang sama tidak berbeda nyata berdasarkan Uji Jarak Berganda Duncan pada Taraf $5 \%$.

Nilai bobot jagung tertinggi terdapat pada perlakuan $\mathrm{H}$, sedangkan bobot jagung terendah terdapat pada perlakuann control (A) dan tanpa pupuk (J). Hal ini sejalan dengan hasil penelitian Fadilah dan Akbar (2015) yang menyatakan bahwa bobot jagung berbeda nyata antara kontrol (tanpa pupuk) dengan perlakuan pupuk P. Perlakuan dosis $\mathrm{P}$ berpengaruh nyata terhadap bobot kelobot jagung hanya pada rentang dosis $0,<1$, dan 1 $1 / 2$ dosis $P$ (Tabel 4). Hal ini tidak sejalan dengan hasil penelitian Fadilah dan Akbar 
(2015) yang menyatakan bahwa dosis P tidak berpengaruh nyata terhadap bobot jagung. Dalam hal ini perlu dipertimbangkan selang dosis P dan media tanam tanaman.

Pada proses pembungaan kebutuhan fosfor akan meningkat drastis karena kebutuhan energi meningkat dan fosfor adalah komponen penyusun enzim dan ATP yang berguna dalam proses transfer energi. Produksi buah yang dihasilkan juga dipengaruhi oleh ketersediaan unsur fosfor dalam tanaman (Sun et al., 2018). Fosfor berperan dalam pemecahan karbohidrat untuk energi, penyimpanan dan translokasinya ke seluruh tanaman dalam bentuk ADP dan ATP terutama pada fase generatif (Leiwakabessy dan Sutandi, 2004). Menurut Subardja dkk. (2017), hal ini menandakan bahwa penggunaan dosis pupuk yang tepat mampu meningkatkan kandungan hara tanaman pada tanah ini, sehingga ketersediaan hara bagi tanaman jagung lebih tercukupi.

\section{KESIMPULAN}

Hasil penelitian menunjukkan bahwa pupuk anorganik SP-36 hasil inovasi yang diberikan bersama dengan urea dan $\mathrm{KCl}$ dapat meningkatkan hasil jagung manis setara dengan hasil jagung pada pupuk NPK perlakuan standar. Hasil terbaik berdasarkan komponen pertumbuhan dan hasil adalah pada dosis $1 \frac{1}{2} \mathrm{P}$ atau setara dengan 150 Kg/Ha SP 36. Perolehan hasil panen jagung manis maksimum dengan dosis ini adalah berkisar 21,16 - 21,56 ton per hektar.

\section{DAFTAR PUSTAKA}

Ayub, M., M.A Nadeem, M.S. Sharar, and N. Mahmood. 2002. Respos of maize (Zea mays L.) fodder to different levels of nitrogen and phosphorous. Asian J. Pl. Sci. 1: $352-354$.

Badan Pusat Statistik (BPS). 2018. Berita Resmi Statistik Tentang Impor
Pangan. Diakses pada 10 Juni 2019 melalui www.bps.go.id.

Fadilah dan Akbar, K. 2015. Pengaruh pemberian pupuk fosfat dan jarak tanam yang tepat terhadap pertumbuhan dan hasil tanaman jagung manis (Zea mays saccharata sturt). Agrosamudra, Jurnal Penelitian 2(2): $71-81$.

Gul, S., M. H. Khan, B. A. Khanday, and S. Nabi. 2015. Effect of sowing methods and NPK levels on growth and yield of rainfed maize (Zea mays L.). Scientifica 2015: 1-6.

Leiwakabessy, F. M. dan Sutandi, A. 2004. Pupuk dan Pemupukan. Departemen Ilmu Tanah. Fakultas Pertanian. IPB, Bogor. [Diktat].

Masood, T., R. Gul, F. Munsif, F. Jalal, Z. Hussain, N. Noreen, H. Khan, Nasiruddin, and H. Khan. 2011. Effect of different phosphorous levels on the yield and yield components of maize. Sahhad J. Agric. 27 (2): 167 - 170.

Olowoake, A. A., O. S. Osunlola, and J. A. Ojo. 2018. Influence of compost supplemented with jatropha on soil fertility, growth, and yield of maize (Zea mays L.) in a degraded soil of Ilorin, Nigeria. International Journal of Recycling of Organic Waste in Agriculture 7(1): 67-73.

Peraturan Menteri Pertanian Nomor: 36/Permentan/SR/10/2017 Tentang: Pendaftaran Pupuk Anorganik.

Puspitasari, H.M., A. Yunus, dan D. Harjoko. 2018. Dosis pupuk fosfat terhadap pertumbuhan dan hasil beberapa tanaman jagung hibrida. Agrosains 20(2): $34-39$.

Rosmarkam, A dan Yuwono, N.W. 2002. Ilmu Kesuburan Tanah. Kanisius, Yogyakarta. 
Santner, J., M. Mannel, L. D. Burrell, C. Hoefer, A. Kreuzeder, W. W. Wenzel. 2014. Phosphorus uptake by Zea mays $\mathrm{L}$ is quantitatively predicted by infinite sink extraction of soil P. Journal Plant and Soil 386(1-2): 371-383.

Subardja, V. Muharam, dan S. Nugraha. 2017. Karakteristik pertumbuhan dan hasil jagung manis di lahan marginal dengan dosis pemupukan yang berbeda. Jurnal Agrotek Indonesia 2(1): $7-12$.

Sun, K., M. Qiu, L. Han, J. Jin, Z. Wang, Z. Pan, B. Xing. 2018. Speciation of phosphorus in plant and manure derived biochars and its dissolution under various aqueous conditions. Sci Total Environ 634: 1300-1307.

Syukur, M. dan Rifianto. A. 2013. Jagung Manis. Jakarta Timur: Penebar Swadaya. 